\title{
Research on Non-English Majors' Interaction and English Learning in the Chinese EFL Classroom
}

\author{
Yuan WANG \\ School of Foreign Languages, Wuhan Textile University, P.R. China, 430200 \\ E-mail: 102171977@qq.com
}

Key words: interaction; comprehensible input; comprehensible output; meaning negotiation

\begin{abstract}
This study examines the relationship between interaction and English learning in the Chinese classroom context and identifies how interactive approach may enhance English learning. Accordingly the aims designed are as follows: 1) to do the research about whether Chinese learners engage in appropriate meaning negotiations in English class and in which type of class they are more likely to engage in meaning negotiations; 2) to study whether interaction promotes learners' mastery of learning materials; 3) to identify whether the interactive approach is superior to the traditional teaching method in developing learners' overall English proficiency.
\end{abstract}

\section{Introduction}

English language teaching (ELT) in China has its own characteristics. [1] [2] Chinese foreign language teaching is conducted in a big country where there is no English-speaking community. [3]English teaching in China has to prepare the students to pass various kinds of exams and develop their communicative competence in English as well. [4] It's obvious that the traditional teaching method based on behaviorism can't accomplish both of the two aims while the interactive teaching approach, which is based on constructivism, humanism and social interactionism and has aroused the interest of many linguists, is good enough to do this challenging task. [5]

\section{Methodology}

\section{A. Research Questions}

This study is to see whether interaction can promote students' English learning in the Chinese classroom context. Accordingly, questions investigated are: 1) whether Chinese learners are engaged in appropriate meaning negotiations in class and in which type of class they are more likely to engage in meaning negotiations; 2) whether interaction promotes learners' mastery of learning materials; 3) whether the interactive approach is superior to the traditional teaching method in developing learners’ overall English proficiency.

B. Subjects

The subjects include 90 students (56 males, 34 females) Management majors. The average age was 20.2 ranging from 19 to 21 belonged to two classes, Class 1 and Class 2, with 45 students in second-year years.

C. Instruments

As Hopkins(1993 cited in McDonough 1997) describes, observation is considered the best to collect required information when the researcher is more interested in the behavior than in the perceptions of the individuals (Kumar 1996). The students' classroom behavior in different class types is what I am interested in. Therefore, this study employs observation as a major source for data collection. 
Table 1 Students average scores in the final exam of the first semester and results of t-test

\begin{tabular}{|c|c|c|c|c|}
\hline & $\begin{array}{c}\text { Final exam } \\
\text { (full score 100) }\end{array}$ & S.D & t-test & $P$ \\
\hline E group & 70.4 & 7.9 & \multirow{2}{*}{0.068} & 0.946 \\
\hline C group & 70.5 & 7.6 & & \\
\hline
\end{tabular}

(Note. E group=the experimental group; $\mathrm{C}$ group= the control group)

Table 1 shows that there is no significant difference in terms of their final exam, indicating that the subjects from the experimental group and the control group were at almost the same level of English proficiency.

Table 2 Four items based on the learning materials and results of t-test

\begin{tabular}{|l|l|c|c|c|}
\hline & $\begin{array}{l}\text { III. Vocabulary 7.5\% } \\
\text { IV. Structure 7.5\% } \\
\begin{array}{l}\text { V. Translation from Chinese to English 30\% } \\
\text { VI. Translation from English to Chinese 5\% } \\
\text { (full score 50) }\end{array}\end{array}$ & S.D & t-test & P \\
\hline E group & 35.7 & 5.2 & .180 & .857 \\
\hline C group & 35.5 & 5.3 & .180 \\
\hline
\end{tabular}

The independent sample t-test was used to measure the significant differences in the subjects' average scores. $\mathrm{P}=.857$, which means that there is no significant difference in terms of the items concerning the learning materials, indicating that the subjects from the experimental group and the control group were of almost the same level as to the mastery of their learning materials.

\section{Results and Discussion}

A. Interaction and meaning negotiations

Table 3 Number of meaning negotiations as\% of total c-units

\begin{tabular}{|c|c|c|c|c|c|c|c|c|c|c|c|c|}
\hline & \multicolumn{2}{|c|}{ C-units } & \multicolumn{2}{|c|}{$\begin{array}{l}\text { C-units } \\
\text { (Total) }\end{array}$} & \multicolumn{2}{|c|}{$\begin{array}{c}\text { Meaning } \\
\text { Negotiations }\end{array}$} & \multicolumn{2}{|c|}{$\begin{array}{c}\text { Meaning } \\
\text { Negotiation } \\
\mathrm{s} \\
\text { (Total) }\end{array}$} & \multicolumn{2}{|c|}{$\begin{array}{c}\text { Negotiation } \\
\text { s/ C-units } \\
\%\end{array}$} & \multicolumn{2}{|c|}{$\begin{array}{c}\text { Negotiatio } \\
\text { ns/ C-units } \\
\text { (Total) } \%\end{array}$} \\
\hline $\begin{array}{l}\text { E group, } \\
1^{\text {st }} \text { Period }\end{array}$ & \multicolumn{2}{|l|}{61} & 61 & & \multicolumn{2}{|l|}{4} & 4 & & \multicolumn{2}{|c|}{6.6} & 6.6 & \multirow{7}{*}{9.0} \\
\hline \multirow{6}{*}{$\begin{array}{r}\text { E group, } \\
2^{\text {nd }} \text { Period }\end{array}$} & Task 1 & 128 & \multirow{6}{*}{614} & \multirow{6}{*}{675} & Task 1 & 15 & \multirow{6}{*}{57} & & Task 1 & $\begin{array}{l}14 . \\
1\end{array}$ & \multirow{5}{*}{10.6} & \\
\hline & Task2 & 91 & & & Task 2 & 9 & & & Task2 & 9.9 & & \\
\hline & Task3 & 130 & & & Task 3 & 11 & & 61 & Task3 & 8.5 & & \\
\hline & Task4 & 102 & & & Task 4 & 10 & & & Task4 & 9.8 & & \\
\hline & Task5 & 111 & & & Task 5 & 12 & & & Task5 & $\begin{array}{l}10 . \\
8\end{array}$ & & \\
\hline & $\begin{array}{l}\text { Follow- } \\
\text { up } \\
\text { activity }\end{array}$ & 52 & & & $\begin{array}{l}\text { Follow-up } \\
\text { activity }\end{array}$ & 0 & & & \multicolumn{2}{|l|}{0} & 0 & \\
\hline $\begin{array}{l}\text { C group } \\
1^{\text {st }} \text { Period }\end{array}$ & \multicolumn{2}{|l|}{11} & \multirow{2}{*}{\multicolumn{2}{|c|}{37}} & \multicolumn{2}{|l|}{1} & \multirow{2}{*}{\multicolumn{2}{|c|}{1}} & \multicolumn{2}{|c|}{3.8} & \multirow{2}{*}{\multicolumn{2}{|c|}{2.7}} \\
\hline $\begin{array}{l}\text { C group } \\
2^{\text {nd }} \text { Period }\end{array}$ & \multicolumn{2}{|l|}{26} & & & \multicolumn{2}{|l|}{0} & & & \multicolumn{2}{|l|}{0} & & \\
\hline
\end{tabular}

The first period of the experimental group and the first and second period of the control group are in whole-class settings. Four meaning negotiations are produced and the incidence of meaning negotiations in the first period of the experimental group is 6.6\%.The incidence of meaning negotiations in the control group is $2.7 \%$. During the two Periods of time, the experimental group 
produce is 61meaning negotiations and the incidence of meaning negotiations is $9.0 \%$ while The control group produces one meaning negotiation and the incidence of meaning negotiations is $2.7 \%$. B. Interaction and the mastery of learning materials

Table 4 Tasks and the academic aims

\begin{tabular}{|c|c|c|c|c|c|}
\hline Task & Task 1 & Task 2 & Task 3 & Task 4 & Task 5 \\
\hline $\begin{array}{l}\text { Academic } \\
\text { aims }\end{array}$ & $\begin{array}{l}\text { 1) words and } \\
\text { expressions } \\
\text { 2) sentence } \\
\text { structures }\end{array}$ & $\begin{array}{l}\text { Listening } \\
\text { comprehension }\end{array}$ & Words & $\begin{array}{l}\text { 1) words and } \\
\text { expressions } \\
\text { 2) patterns of } \\
\text { giving } \\
\text { suggestions } \\
\text { 3) letter writing }\end{array}$ & $\begin{array}{l}\text { 1) words and } \\
\text { expressions } \\
\text { 2) comprehension } \\
\text { of implied } \\
\text { meanings }\end{array}$ \\
\hline
\end{tabular}

Table 6 displays that the general curriculum, the contents of the course, the textbooks and even the speed of teaching are all determined. Therefore teachers are much constrained when they try to design interactive activities. They should base the activities strictly on the textbooks or else they will not finish their teaching tasks.

C. The increased use of the target language

Table 5 Number of C-units from the $\mathrm{E}$ and $\mathrm{C}$ groups

\begin{tabular}{|c|c|c|c|}
\hline \multirow{2}{*}{} & \multicolumn{2}{|c|}{ C-units } & \multicolumn{2}{|c}{$\begin{array}{c}\text { C-units } \\
\text { (Total) }\end{array}$} \\
\hline \multirow{2}{*}{$\begin{array}{c}\text { E group, } \\
1^{\text {15 }} \text { Period }\end{array}$} & \multicolumn{2}{|c|}{61} & 61 \\
\hline \\
\hline
\end{tabular}

Table 5 shows that the Experimental group produces altogether 675 c-units while the control group produces 37 c-units during two periods of time. It was during the study of their learning material that they made the output and found their linguistic problems and reformulated their utterances. Therefore the increased use of the target language can be of great help to their mastery of the learning material.

D. Errors in the subjects' output

Table 6 Errors in the subjects' output in whole-class settings

\begin{tabular}{|c|c|c|c|c|}
\hline Group & E group & E group & C group & $\begin{array}{c}\text { C } \\
\text { group }\end{array}$ \\
\hline Time & $1^{\text {st }}$ period & $\begin{array}{c}2^{\text {nd }} \text { period } \\
\text { Follow-up activities }\end{array}$ & $1^{\text {st }}$ period & $\begin{array}{c}2^{\text {nd }} \\
\text { period }\end{array}$ \\
\hline Errors & 29 & 3 & 10 & 8 \\
\hline
\end{tabular}

Errors in the subjects' output in whole-class settings are displayed in Table 8. The second period of the control group made the least errors while the first period of the experimental group makes the most. 
Table 7 Errors in the subjects' output in group-work settings

\begin{tabular}{|c|c|c|c|c|c|c|}
\hline & Task 1 & Task 2 & Task 3 & Task 4 & Task 5 & Total \\
\hline Errors & 73 & 31 & 51 & 42 & 75 & 272 \\
\hline
\end{tabular}

In group-work settings, the fewest errors while the as shown in Table 9, the group doing Task 2 group doing Task 5 makes the most. Altogether 272 errors are made during the group activities.

Table 8 Number of errors as\% of total c-units of $\mathrm{E}$ and $\mathrm{C}$ groups

\begin{tabular}{|c|c|c|c|}
\hline & Errors & c-units & $\begin{array}{c}\text { Errors/c-units } \\
\%\end{array}$ \\
\hline $\begin{array}{c}\text { E group } \\
1^{\text {st }} \text { Period }\end{array}$ & 29 & 61 & 47.5 \\
\hline $\begin{array}{c}\text { E group } \\
\text { Group work }\end{array}$ & 272 & 562 & 48.4 \\
\hline $\begin{array}{c}\text { Follow-up } \\
\text { activities }\end{array}$ & 3 & 52 & 5.8 \\
\hline $\begin{array}{c}\text { C group } \\
1^{\text {st } \& 2^{\text {nd }} \text { Period }}\end{array}$ & 18 & 37 & 48.6 \\
\hline
\end{tabular}

The incidence of errors in whole-class settings and in group-work is displayed in Table 10 . The percentages are shown in the right column. The percentage of group-work is $0.2 \%$ lower than that of the control group. The percentage of the follow-up activities is the lowest (5.8\%).

E. Error treatment

Table 9 Error treatment in whole-class settings

\begin{tabular}{|l|c|c|c|}
\hline & Errors & Corrected errors & $\begin{array}{c}\text { corrected errors / } \\
\text { errors }\end{array}$ \\
\hline $\begin{array}{c}\text { E group } \\
1^{\text {st }} \text { period }\end{array}$ & 29 & 18 & $78.3 \%$ \\
\hline $\begin{array}{c}\text { E group } \\
2^{\text {nd }} \text { period } \\
\text { Follow-up activities }\end{array}$ & 3 & 2 & $66.7 \%$ \\
\hline $\begin{array}{c}\text { C group } \\
1^{\text {st }} \text { period }\end{array}$ & 10 & 9 & $90 \%$ \\
\hline $\begin{array}{c}\text { C group } \\
2^{\text {nd }} \text { period }\end{array}$ & 8 & 8 & $100 \%$ \\
\hline
\end{tabular}

Table 9 shows the number of errors and the number of corrected errors in whole-class settings. The percentages of corrected errors to errors are listed in the right column. The errors in the second period of the control group are all corrected while most of the errors are corrected in other cases.

Table 10 Error treatment in group-work settings

\begin{tabular}{|c|c|c|c|}
\hline & Errors & Noticed errors & $\begin{array}{c}\text { Noticed errors / } \\
\text { errors }\end{array}$ \\
\hline Task 1 & 73 & 38 & $52.1 \%$ \\
\hline Task 2 & 31 & 12 & $38.7 \%$ \\
\hline Task 3 & 51 & 19 & $37.3 \%$ \\
\hline Task 4 & 42 & 36 & $85.7 \%$ \\
\hline Task 5 & 75 & 18 & $24 \%$ \\
\hline Total & 272 & 123 & $45.2 \%$ \\
\hline
\end{tabular}


Table 10 shows the number of errors, include: errors corrected by the speaker himself or the other partners; errors which the speaker himself or the other partner has noticed but failed to give proper corrections. The percentages range from $24 \%$ to $85.7 \%$.

F. Post-test of the overall English proficiency

Table 11 Students average scores in the final exam of the third semester

\begin{tabular}{|c|c|c|c|c|}
\hline & $\begin{array}{c}\text { Final exam } \\
\text { (full score } \\
100)\end{array}$ & S.D & t-test & $\mathrm{P}$ \\
\hline E group & 72.7 & 7.7 & 3.119 & .002 \\
\hline C group & 68.0 & 6.4 & \\
\hline
\end{tabular}

Table 11 shows that in the subjects' average scores of the third semester, $\mathrm{P}=.002$, which means that there is a significant difference in terms of their final exam, indicating that after two terms' study with different ways of teaching, some changes have taken place. The interactive approach seems superior to the traditional method in improving students' overall English proficiency.

\section{Conclusion}

The interactive approach can promote learners English learning in the Chinese EFL classroom. It is the different ways of teaching that have made that difference. English learners in China do engage in meaning negotiations, but they perform very differently in different types of class. Interactive activities in the EFL classroom are based on the learning material. They provide more opportunities for learners to use their learning content in a certain context. The results of the post-test suggest interaction can promote learners' mastery of learning materials. If it is confirmed that interaction can enhance English learning in the Chinese EFL classroom, it is advisable for teachers to make use of the findings concerning interaction and create more opportunities for learners to participate in interaction in their language classroom. By doing further studies, the relation between interaction and English learning in the Chinese classroom context will hopefully become clearer and it will attract more and more attention from both teachers and learners.

\section{Acknowledgement}

In this paper, the research was sponsored by Schoo1-based Research Project of Wuhan Textile University in 2015 (Project No. 20150055).

\section{References}

[1] Levinson Stephen C.Pragmatics. Journal of Women s Health . 2001

[2] Rémi A. van Compernolle,Lawrence Williams. The effect of instruction on language learners' sociolinguistic awareness: An empirical study with pedagogical implications[J]. System . 2013 (2)

[3] Jennifer Miller. Teaching Refugee Learners with Interrupted Education in Science: Vocabulary, literacy and pedagogy[J]. International Journal of Science Education . 2009 (4)

[4] Aida Walqui. Scaffolding Instruction for English Language Learners: A Conceptual Framework[J]. International Journal of Bilingual Education and Bilingualism . 2006 (2)

[5] Amy Snyder Ohta. Interlanguage pragmatics in the zone of proximal development[J]. System . 2005 (3) 